pÿResponse to the comment on Abdominoplasty in massive pÿweight loss patient: Modifying the technique to improve the safety

\title{
Pajula, Susanna
}

2019-06

Pajula , S , Jyränki , J , Tukiainen , E \& Koljonen , V 2019 , ' Response to the comment on pÿ Abdominoplasty in massive weight loss patient: Modifying the technique to improve the pÿsafety ' , Journal of Plastic, Reconstructive \& Aesthetic Surgery, vol. 72 , no. 6 , pp. 1037-1037 . https://doi.org/10.1016/j.bjps.2019.03.018

http://hdl.handle.net/10138/313872

https://doi.org/10.1016/j.bjps.2019.03.018

cc_by_nc_nd

Downloaded from Helda, University of Helsinki institutional repository.

This is an electronic reprint of the original article.

This reprint may differ from the original in pagination and typographic detail.

Please cite the original version. 


\section{Accepted Manuscript}

Response to the comment on "Abdominoplasty in massive weight loss patient: modifying the technique to improve the safety"

Susanna Pajula MD , Janne Jyränki MD ,

Erkki Tukiainen MD, PhD , Virve Koljonen MD PhD

PII:

S1748-6815(19)30128-7

DOI: https://doi.org/10.1016/j.bjps.2019.03.018

Reference: PRAS 6027

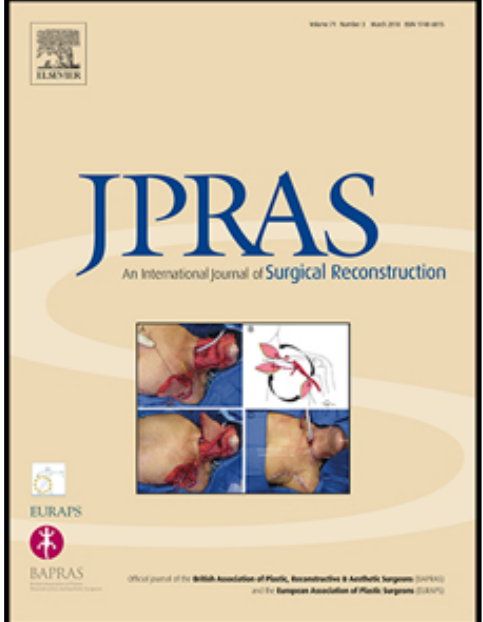

To appear in:

Journal of Plastic, Reconstructive \& Aesthetic Surgery

Received date:

4 March 2019

Accepted date:

10 March 2019

Please cite this article as: Susanna Pajula MD, Janne Jyränki MD, Erkki Tukiainen MD, PhD, Virve Koljonen MD PhD , Response to the comment on "Abdominoplasty in massive weight loss patient: modifying the technique to improve the safety", Journal of Plastic, Reconstructive \& Aesthetic Surgery (2019), doi: https://doi.org/10.1016/j.bjps.2019.03.018

This is a PDF file of an unedited manuscript that has been accepted for publication. As a service to our customers we are providing this early version of the manuscript. The manuscript will undergo copyediting, typesetting, and review of the resulting proof before it is published in its final form. Please note that during the production process errors may be discovered which could affect the content, and all legal disclaimers that apply to the journal pertain. 
Response to the comment on "Abdominoplasty in massive weight loss patient: modifying the technique to improve the safety"

Susanna Pajula, MD, Janne Jyränki, MD, Erkki Tukiainen, MD, PhD, Virve Koljonen, MD, PhD

Department of Plastic Surgery, University of Helsinki and Helsinki University Hospital, Helsinki, Finland

We thank Dr. Gentileschi and colleagues for commenting our article; Complications after lower body contouring surgery due to massive weight loss unaffected by weight loss method ${ }^{1}$ and interest in our work.

We agree with Dr. Gentileschi et al. ${ }^{2}$ that especially in massive weight loss (MWL) patients the number of complications is related to body contouring technique used. Our study presented single centre experience on MWL lower body contouring surgery. In our centre, we have used technique with limited upper flap - above umbilicus - lateral undermining to tunnel in the apex and raising the flap on the muscle fascia plane. Below the umbilicus, Scarpa's fascia is usually preserved in some 5-10 cm above the incision. As Gentilechi et al. point out, it is unclear why the preservation of Scarpa's fascia seem to reduce the number of certain complications or does preserving technique not provide any additional benefit, as our study showed ${ }^{1}$.

Regarding biliopancreatic diversion, we confirm that none of the patients in our series had this operation. We included all MWL patients operated in our department during the time frame described in our article with no exclusion based on bariatric surgery technique. To best of our knowledge the biliopancreatic diversion operation is usually reserved for second line operation for morbid obesity in Finland. Finnish national study during 2009 - 2013 among 3918 patients who undergone surgery for morbid obesity, only $2.6 \%$ had biliopancreatic diversion with or without duodenal switch ${ }^{3}$. Therefore, we have no expertise on commenting whether the good results in our study were due to absence of biliopancreatic diversion and rely on the data presented by Tambasco et al. ${ }^{4}$.

When designing and drafting our article we obviously oriented to most of the previous articles. We found, that systematic grading of post-operative complications was seldom used. Based on our experience, we suggest that grading systems such as Clavien-Dindo, should be used in future studies. Systemic grading makes the comparison of results objective and ensues fruitful academic discussion.

Corresponding Author:

Susanna Pajula

Department of Plastic and General Surgery

Kiinanmyllynkatu 4-8, 20521 Turku, Finland Tel: +358 407197294

Email:susanna.pajula@tyks.fi

Conflict of interest and funding: None declared 
1. Pajula S, Jyranki J, Tukiainen E, Koljonen V. Complications after lower body contouring surgery due to massive weight loss unaffected by weight loss method. J Plast Reconstr Aesthet Surg 2018 December 15.

2. Bracaglia R, D'Ettorre M, Gentileschi S, Tambasco D. "Vest over pants" abdominoplasty in postbariatric patients. Aesthetic Plast Surg 2012 February 01;36(1):23-7.

3. Bockelman C, Hahl T, Victorzon M. Mortality following bariatric surgery compared to other common operations in finland during a 5-year period (2009-2013). A nationwide registry study. Obes Surg 2017 September 01;27(9):2444-51.

4. Tambasco D, D'Ettorre M, Gentileschi S, Colletti R, Mingrone G, Bracaglia R.

Postabdominoplasty wound dehiscence in bariatric patients: Biliopancreatic diversion versus gastric bypass: A preliminary study. Ann Plast Surg 2015 December 01;75(6):588-90. 